\title{
Consumer Preference and Willingness to Pay for the Tourism Packages: A Conjoint Study of a Rural Destination
}

\author{
Eric Beckman ${ }^{1}$, Kuo-Liang "Matt" Chang ${ }^{2}$ \\ ${ }^{1}$ Ph.D. CHE, Chaplin School of Hospitality and Tourism Management, Florida International University, 3000 Northeast \\ 51 Street, North Miami, FL. 33181, USA \\ ${ }^{2} \mathrm{PhD}$, Box 504; Scobey Hall Room 109; Department of Economics, South Dakota State University, Brookings, SD, \\ USA \\ Correspondence: Eric Beckman, Ph.D. CHE, Chaplin School of Hospitality and Tourism Management, Florida \\ International University, 3000 Northeast ${ }^{2} 51$ Street, North Miami, FL. 33181, USA
}

Received: March 5, 2018

Accepted: March 26, 2018

Online Published: March 27, 2018

doi:10.11114/bms.v4i2.3075

URL: https://doi.org/10.11114/bms.v4i2.3075

\begin{abstract}
Many small cities and towns seek to promote their destinations to leisure travelers via their website. Leisure travelers consist of singles, couples, families, and friends travelling together. While not part of the more lucrative group market, leisure travelers are nonetheless important to the economy of a destination. For instance, families that travel are looking for the types of restaurants, hotels, and activities that are family-friendly. Couples may be looking for a romantic getaway including a charming hotel and a pleasant restaurant. Some destinations will attempt to cater to these travelers by providing packages on their website that cater to families and couples. Thus, it is important to determine what types of packages families (and couples) want for their trip, the perceived value of the packages, and how much they would be willing to pay for these packages. This study uses a choice-based conjoint study to determine willingness to pay (WTP) for various package choices geared towards families in a rural destination.
\end{abstract}

Keywords: choice-based conjoint, tourism packages, sporting events, bundling, place marketing

\section{Introduction}

Selling travel packages is a well-accepted marketing strategy to promote a destination's tourism business (Dellaert, Borgers, \& Timmermans, 1995). This process, also known as bundling, involves combining two or more services or products into a value-priced package (Guiltinan, 1987). Today, more and more consumers are browsing and purchasing online travel packages (Bracco, 2013; James, Ravichandran, Chuang, \& Bolden, 2017; Tanford, Baloglu, \& Erdem, 2012). Many DMOs (Destination Marketing Organizations) use travel packages on their website to promote the destination to tourists. Websites of destination marketing organizations such as Sioux Falls Convention and Visitor's Bureau or Ottawa Tourism have travel packages offered to leisure travelers year-round targeting families and couples (Elliot \& Joppe, 2010). These DMO's realize the value of new money that these leisure travelers bring to a destination.

States, provinces, counties and cities use DMOs (destination marketing organizations) to promote tourism to their destination. Many of these DMO's work with hotels, local attractions, and seasonal events to provide travel packages for the destination they represent. These attractions include unique activities to the destination such as theme parks, zoos, museums, and local restaurants (featuring local, regional cuisine) (Bracco, 2013; James et al., 2017). In bundling these unique activities, DMOs provide a convenience to the consumer. The potential tourist can book their trip via the DMO website utilizing a single transaction. Additionally, these packages are typically provided at a reduced rate (than purchasing each package item separately) (J. Kim, Bojanic, \& Warnick, 2009). Thus, these potential tourists see value and convenience for each of the packages provided on DMO websites. Each of the businesses involved in the packages see increased visitation to their restaurants, hotels, theme parks, museums, and zoos (James et al., 2017). The success of travel packages that promote a destination is heavily relied upon whether the services/products being offered are unique and desirable. In selecting the unique products/services that a destination has to offer, researchers can help destination marketing professionals effectively utilize these products/services in travel package offerings on a destination website.

There has been limited research on visitor preferences for tourism-related packages for destinations. Past research on the identification of desired travel packages has been primarily centered on the bundling of air and hotel amenities but has not included any food options or other types of activities specific to the destination. These limited studies primarily focus on travel packages to popular urban destinations such as Las Vegas (Dellaert et al., 1995; Tanford et al., 2012). 
Still fewer studies have utilized choice-based conjoint analysis to analyze the real-time preference of potential tourists to a destination (Zhao \& Chen, 2017). Thus, a large gap in the research exists, as many travel packages go beyond offering just airfare and hotel nights for an urban destination. The goal of this study is to provide a greater insight into the selection of multiple components for travel packages at a rural destination.

\section{Research Objectives}

1. Examine consumers' preferences for travel packages if they were to visit a rural destination in the Upper Midwest of the United States.

2. Examine consumers' willingness to pay (WTP) for travel packages when visiting a rural destination in the Upper Midwest of the United States.

\section{Literature Review}

\subsection{Place Marketing}

Many different types of places are marketed, including countries, regions, counties, cities and towns (Boo, Busser, \& Baloglu, 2009; Boo, 2011; Usakli \& Baloglu, 2011). As mentioned above, some of these places support the idea of travel packages. These cities often include travel packages on their websites in order to encourage leisure travelers to visit their destination for the unique experiences that these destinations provide (Beckman, Kim, \& Kumar, 2013; Bracco, 2013; Elliot \& Joppe, 2010; James et al., 2017). Many of these destinations are marketing their city using different forms of art and creativity native to the city. Cities can market themselves via various creative strengths including performing arts, music, sports, and film (Lim \& Bendle, 2011; O’Connor \& Flanagan, 2008; Phillips \& Schofield, 2007; Ward \& O'Regan, 2009). Other unique experiences include museums, theme parks, seasonal events (festivals), and zoos (James et al., 2017; K. Kim \& Uysal, 2003).

\subsection{Online Travel Packages}

As mentioned above, selling travel packages is also called bundling, and is a well-known and accepted way to create destination value in the mind of the leisure traveler (Dellaert et al., 1995; Tanford et al., 2012). Packages are bundled when two or more travel items are combined (i.e. hotel and airfare) in a discounted package. Selling travel packages has increased dramatically online with online travel agencies (OTAs) bundling car-rental, airfare, and hotel rates (Buhalis \& Law, 2008). When booking these amenities together the online consumer receives a discounted rate in comparison to booking airfare, hotel, and rental car separately (J. Kim, Kim, \& Kim, 2018; J. Kim, Bojanic, \& Warnick, 2009).

The prices for OTA packages are often dynamic in price. Dynamic pricing occurs when the price for a package may go up or down depending on the supply and demand related to the hotel, airfare, and car rentals available (Ayazlar, 2014; Buhalis \& Law, 2008; Cardoso \& Lange, 2007; J. Kim et al., 2018). The higher the demand for such products, the more the travel package may cost. These costs can also vary based on seasonality (J. Kim et al., 2009). Travel consumers have the choice to select premium or economy hotels, car rentals and airfare. Thus, they can customize their travel package with the types of travel options and the quality of options as desired (Ayazlar, 2014).

An alternative to dynamic pricing, some travel packages remain constant in price and product/service inclusion. These types of travel packages are called static rather than dynamic. Static packages are often offered on DMO websites promoting the destination to leisure travelers on the local, regional, and international level (Ayazlar, 2014; Buhalis \& Law, 2008; Rose, 2004). Though offered at a discount, these packages cannot be altered/changed and are booked at one price for each package. Other websites that offer static packages include travelinfomration.com and freetravelguides.com (J. Kim et al., 2018).

In addition to the price reduction, other perceived benefits that travel packages provide include convenience, increase in overall consumer satisfaction, and increased attractiveness of travel options at the destination (Bruzza, Cabrera, \& Tupia, 2017; Buhalis \& Law, 2008; J. Kim et al., 2018; Zhao \& Chen, 2017). The convenience of travel packages includes booking multiple items at once (airfare, hotel, restaurants, museum). The increased satisfaction occurs when the consumer perceives that he obtained a value for his purchase. The attractiveness of the destination occurs when the packages offered are desirable for the type of consumer segment being targeted (Kim et al., 2018).

\subsection{Prospect Theory}

This study utilizes prospect theory to explain how customers go about selecting travel packages for a destination. Prospect theory identifies the consumer as someone who mentally computes the savings and monetary value associated with bundled products and chooses the (bundled product) with the greatest value (Kahneman \& Tversky, 1979). Consumers perceive good value when the travel package includes every product/service the customer expected, and there are no hidden costs in the travel package. On the contrast if the consumer feels the package was incomplete and 
there are unanticipated additional charges, the perceived value of the travel package will decrease (Chiam, Soutar, \& Yeo, 2009; Naylor \& Frank, 2001).

\section{Methodology}

In this study, sporting event participants (adult family members) were surveyed to determine the types of activities that would create a favorable enough impression to revisit the town. Visitors to one of two sporting events in a rural destination were surveyed (at the event) utilizing a street-intercept survey method. For the rural destination, researchers determined unique attributes (activities) that may attract the traveling family to Brookings, S.D. The activities selected were exclusive to the destination and thus more likely to influence a family to return to the destination. The researchers included these activities (hotel, widely-known museum, waterpark) in a Choice-Based Conjoint (CBC) analysis (Batsell \& Lodish, 1981; Louviere \& Woodworth, 1983). The CBC analysis is a multi-attribute decisional method (quantitative) that allows the researchers to control the attributes across choice sets to test the research objectives (Banerjee, Hudson, \& Martin, 2007). By combining the advantages of conjoint experiment analysis and discrete choice modeling, the researchers are able to algebraically describe and individual's utility for a specific tourism attraction and to mimic consumer's actual consumption behavior (Louviere \& Woodworth, 1983; Mayen, Marshall, \& Lusk, 2007).

The survey questionnaire contained questions to conduct the CBC experimental study. Adult family and friends of those participating in the sports tournaments were provided 2 scenarios of travel-package choices. The instructions included: 'Please select one of the following four options that you would prefer in a family trip to Brookings, SD,' ( 3 packages and one opt-out). The respondents selected the most appealing choice in each of the two scenarios. The second part of the survey included a question set aiming to acquire respondents' demographic and socio-economic information. A careful examination of the information gathered in this section enabled us to gain a better understanding of the population who visited the town during the two events we delivered the collected survey questionnaires.

\section{Instrument}

For section 1, researchers incorporated the town attractions to develop hypothetical tourism packages (products) to examine consumers' preference and WTP (willingness to pay) for these attractions, with an emphasis on the impacts of consumers' differences in characteristics. Ideally we would prefer to study all the attractions and their attributes that the town might offer to attract visitors. However, we would have to increase the length and complexity of survey design whenever an additional attraction was included in the survey. A long questionnaire with complex questions might negatively affect the participation rate and the quality of the responses; it could also damage the quality of the statistical analysis given that the degree of freedom decreased noticeably with the increase of attributes. Therefore, we had to minimize the number of the attributes while focusing on the main attractions of the town.

The researchers conducted a preliminary (pilot) study with a small group of interviewees to gather information needed to improve the experimental design. With the results of the pilot study combined with the information gathered from our conversations with local tourism marketers, we finalized the key attractions (Children's Museum and Waterpark) to be utilized in the choice-based conjoint (CBC) analysis. Other attractions (hotel, restaurant voucher, bowling) were used for supplemental attributes. Once the attractions were selected, the next task was to transform the research objects and to develop an effective questionnaire that contained product profiles for respondents to correctly respond (Mayen et al., 2007). Accordingly, we decided each questionnaire would contain two choice sets to enhance the quality of the survey. For each choice set, there were four options (i.e., three products and one opt-out option) for the survey participants to choose only one option. We assigned a 'theme' for each of the three options (products) that highlighted the main attractions of the town. Despite the difference in the themes, all three product options shared the other attractions included with various details.

The first product option (i.e., Museum Package) offered two adults and two children's pass to the children's museum (attracted 300,000 visitors since it opened in 2010). The theme for the second product option (i.e., Water Park Package) offered two adults and two children's passes to an outdoor aquatic center located in the center of the town. The aquatic center has been a popular recreation location in the summer for its variety of outdoor pools. The third product option (i.e., Combo Package, later titled as 'MW') combined the previous two packages that offered two adults and two children passes to both the children museum and the aquatic center. All three options (products) shared the other attributes including price of the package (i.e., the default variable for the CBC survey questionnaires), hotel options, restaurant coupons, and passes to a local bowling alley. The levels of these attractions were varied and randomly assigned. See figure 1 for the $\mathrm{CBC}$ survey design. 
Please select one of the following four options that you would prefer in a family trip to Brookings, SD ( 3 packages and one opt-out):

\begin{tabular}{|c|}
\hline Package Options \\
\hline Hotel (one night) \\
\hline Local Restaurant \\
Vouchers \\
\hline Bowling at \\
\hline Prairie Lanes \\
\hline Package Purchase Price \\
\hline Select One Option \\
\hline \\
\hline Package Options \\
\hline \\
\hline Hotel (one night) \\
\hline Local Restaurant \\
\hline Vouchers \\
\hline Bowling at \\
\hline Prairie Lanes \\
\hline Package Purchase Price \\
\hline Select One Option \\
\hline
\end{tabular}

\begin{tabular}{|c|}
\hline $\begin{array}{c}\underline{\text { Option 1 }} \\
\text { Children Museum Passes } \\
\text { (2 Adults + 2 Children) }\end{array}$ \\
\hline Upper Midscale Hotel \\
\hline$\$ 40$ \\
\hline None \\
\hline$\$ 130$ \\
\hline
\end{tabular}

\begin{tabular}{|c|}
\hline Option 1 \\
Children Museum Passes \\
(2 Adults + 2 Children) \\
\hline Midscale Hotel \\
\hline$\$ 20$ \\
\hline None \\
\hline$\$ 175$ \\
\hline
\end{tabular}
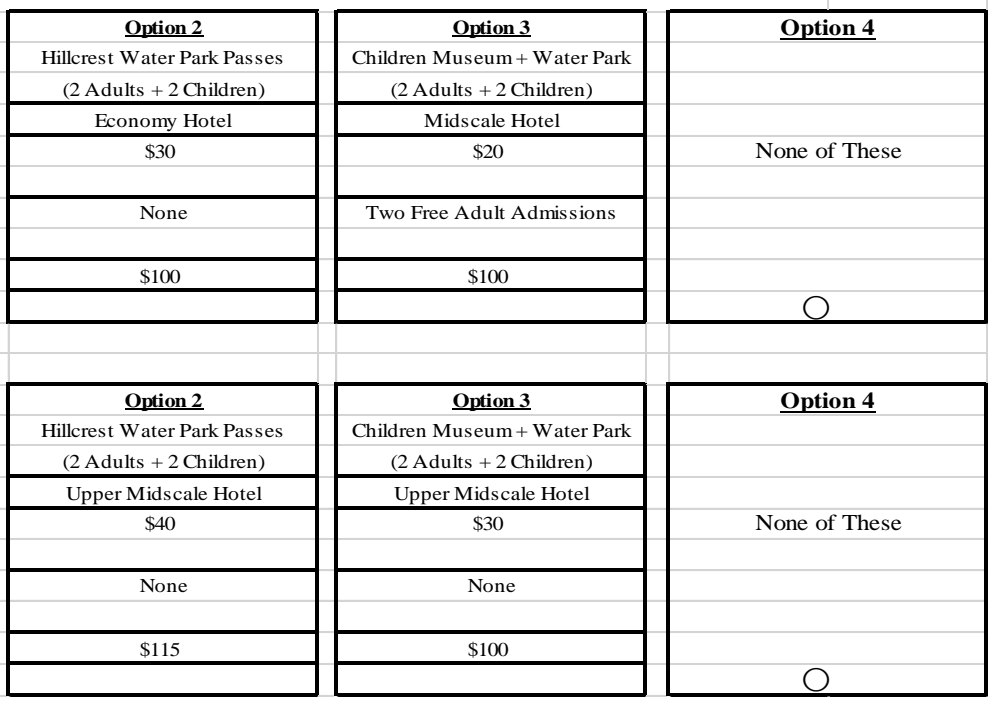

Figure 1. Travel Packages

\section{Results}

Visitors to one of two sporting events in a rural destination were surveyed (at the event) utilizing a street-intercept survey method. Response rate for the survey was $95 \%$ as the researchers offered a voucher for free food at the concession stand. A total of 309 paper survey questionnaires were returned and 275 questionnaires were usable for the CBC analysis after discarding the surveys with unrealistic values and outliers. We also discarded the surveys if respondents did not answer the CBC questions. The overall usable response rate for the study is approximately $89.3 \%$. Of the 275 respondents, 123 were male (44.7\%) and 152 were female (55.3\%). Regarding ethnicity, 260 of 275 respondents were Caucasian (94.5\%), 15 respondents were another ethnicity (5.5\%). On marital status, $63(22.9 \%)$ of 275 respondents were single, $202(73.5 \%)$ were married and $10(3.6 \%)$ were separated, widowed or divorced. The average age of the event attendees was 40.6 years.

Regarding a choice-based conjoint analysis, it is generally accepted that samples with 75 or more respondents contribute reliable results (McCullough, 2002). Thus, the 275 respondents surveyed provided more than required sample number to sustain reliability.

Respondents indicated a preference for the combined travel package of children's museum and waterpark. Another important objective for this study was to estimate visitors' WTP to obtain an exact level of a tourism attraction (Greene, 2000). The following table summarizes the estimated WTP's (willingness to pay) and corresponding standard deviation. Table 1 suggests that our sample respondents expressed statistically significant WTPs for the combination package (M/W) in both models. However, while the WTP for the M/W package (product) was $\$ 186.86$ for the Basic Model we also found the WTP for the same package dropped to $\$ 131.73$ after controlling the survey location (i.e., Model 2). The survey location included adults at a soccer tournament and a softball tournament. Table 1 illustrated that our sample respondents did not obtain significant WTPs for the children's museum package or the water park package. Our sample respondents were willing to pay approximately $\$ 95.99$ to upgrade from economy hotels to upper-midscale hotels.

Table 1. Willingness to pay

\begin{tabular}{l|c|c}
\hline Changes in Attributes & Basic Model & Model 2 (Event) \\
\hline Children Museum Package & $\$ 49.91$ & $\$ 55.09$ \\
$(2$ adults +2 children) & $(27.72)$ & $(112.99)$ \\
\hline Water Park Package & $\$ 151.85$ & $\$ 95.98$ \\
(2 adults + 2 children) & $(83.57)$ & $(109.80)$ \\
\hline Children Museum and Water Park (M/W & $\$ 186.86^{*}$ & $\$ 131.73^{*}$ \\
Package) & $(23.61)$ & $(54.82)$ \\
\hline Economy to Upper Midscale Hotels & $\$ 95.98^{*}$ & $\$ 95.99^{*}$ \\
& $(31.39)$ & $(31.04)$ \\
\hline
\end{tabular}

Note: *: Statistically significant from zero. 


\section{Theoretical Contributions}

This study employed prospect theory to explain how customers go about selecting travel packages for a rural destination. When sporting event participants filled out the survey, they mentally computed the savings and monetary value associated with bundled products and chose the (bundled product) with the greatest value (Kahneman \& Tversky, 1979). Because the children's museum is well-known and a positive attribute of the destination for families, the researchers anticipated that future visitors would perceive substantial value when the travel package includes the types of products and services that appeal to the family. Similarly, many visitors to Brookings are aware of the large waterpark in the town. If we had left either of these major attributes out, the consumer may have felt the package was incomplete, thus the perceived value of the travel package would decrease (Chiam et al., 2009; Naylor \& Frank, 2001).

\section{Marketing Implications}

Researchers selected travel packages that appealed to the family leisure tourist over couples and singles based on the options available in Brookings, S.D. Brookings is home to a widely-known Children's Museum. Pair this museum with a large (seasonal) waterpark and many families surveyed would be willing to return to Brookings at a value price of $\$ 131.73$ (including tickets for 2 adults and two children to both options). Online travel agencies (OTAs) have few options for packaging when it comes to rural destinations. In the case of Brookings, there are no car rentals or flights, only hotels. Thus, the DMO (Brookings CVB) may be the sole provider of online travel packages if it were to post family-friendly packages on its website. From the above example, tourism marketers at DMO's should be aware that the more options bundled together in a travel package, the greater the perceived value of that package. Additionally, tourists will be willing to pay more for the package when bundled with several activities (that appeal to the targeted consumer). In the case of a rural destination such as Brookings, the children's museum (famous in the Upper Midwest) was bundled with the water park and a hotel room to maximize the value of the package.

\section{Discussion and Future Studies}

The purpose of this study was to 1) examine consumers' preferences for travel packages and 2) consumers' willingness to pay (WTP) for travel packages. The researchers addressed gaps in the research in determining travel package preferences in a rural destination. The researchers also included recommendations for future research in the study by including tickets to a tourist attraction in our primary travel packages (J. Kim et al., 2009). A Choice-Based Conjoint (CBC) analysis was applied that combined the advantages of conjoint experiment analysis and discrete choice modeling to examine visitor's utility for a specific town attraction and to measure their WTP for each attraction in interest. For both models, it was shown that visitors to Brookings preferred the MW (combination museum and waterpark) package over the packages that included only the waterpark or only the museum. In order to revisit Brookings, visitors perceived significant value with the MW choice over the package choices that included just one of the primary package choices (Noone \& Mattila, 2009). Thus, if the Brookings CVB would offer a family trip to Brookings which includes tickets to the museum/waterpark at $\$ 131.73$ (willingness to pay), many of the families surveyed would be willing to revisit based on that perceived value.

The researchers were limited in the types of family packages that could be created given the small nature of the town and lack of family-related attractions. Other towns and cities could prove to be more useful in assembling packages and provide more meaningful data (towns with theme parks). The more types of activities that exist, the more researcher can help marketers focus on various segments (i.e. family, couples, etc.). Larger towns will have more varied types of family activities and thus researchers can survey potential visitors to find the optimal packages and perceived value.

Future studies should control for each activity, hotel price, restaurant voucher, and miles travelled to determine the optimum package or packages that appeal to most visitors. Furthermore, future studies should determine optimal travel packages in other towns to determine the types of activities (packaged together) that will bring the greatest chance the visitor will return in the future. Unique aspects of the town (different options) should be explored for each segment. Unique attributes including restaurants, resorts, sports (golf, watersports), tours, theme parks, zoos, retail districts, and museums should be leveraged to appeal to multiple leisure segments depending on the destination.

\section{References}

Ayazlar, R. A. (2014). Dynamic Packaging Applications in Travel Agencies. Procedia - Social and Behavioral Sciences, 131, 326-331. https://doi.org/10.1016/j.sbspro.2014.04.125

Banerjee, S., Hudson, D., \& Martin, S. (2007). Effects of Seed and Farm Characteristics on Cottonseed Choice: A Choice-Based Conjoint Experiment in the Mississippi Delta. Journal Of Agricultural and Applied Economics, 39(3), 657-669. https://doi.org/10.1017/S1074070800023336

Batsell, R., \& Lodish, L. (1981). A model and measurement methodology for predicting individual consumer choice. Journal of Marketing Research, 18(February), 1-12. https://doi.org/10.2307/3151309 
Beckman, E., Kim, Y. K., \& Kumar, A. (2013). The impact of brand experience on downtown success. Journal of Travel Research, 52(5), 646-658. https://doi.org/10.1177/0047287513478502

Boo, S. (2011). Destination Brand Attitude and Loyalty as Factors in Revisitation of Competitive Destinations. Tourism Review International, 14, 163-178. https://doi.org/10.3727/154427211X13092645879892

Boo, S., Busser, J., \& Baloglu, S. (2009). A model of customer-based brand equity and its application to multiple destinations. Tourism Management, 30(2), 219-231. https://doi.org/10.1016/j.tourman.2008.06.003

Bracco, T. (2013). Summer $\quad$ Staycations. $\quad$ Retrieved from http://bizeconreporting.journalism.cuny.edu/2013/05/13/summer-staycations/

Bruzza, M., Cabrera, A., \& Tupia, M. (2017). Survey of the state of art based on PICOC about the use of artificial intelligence tools and expert systems to manage and generate tourist packages. In Infocom Technologies and Unmanned Systems (Trends and Future Directions)(ICTUS), 2017 International Conference on (pp. 290-296). https://doi.org/10.1109/ICTUS.2017.8286021

Buhalis, D., \& Law, R. (2008). Progress in information technology and tourism management: 20 years on and 10 years after the Internet-The state of eTourism research. Tourism Management, 29(4), 609-623. https://doi.org/10.1016/j.tourman.2008.01.005

Cardoso, J., \& Lange, C. (2007). A Framework for Assessing Strategies and Technologies for Dynamic Packaging Applications in E-Tourism. Information Technology \& Tourism, 9(1), 27-44. https://doi.org/10.3727/109830507779637585

Chiam, M., Soutar, G., \& Yeo, A. (2009). Online and off-line travel packages preferences: A conjoint analysis. International Journal of Tourism Research, 11 (September 2008), 31-40. https://doi.org/10.1002/jtr.679

Dellaert, B., Borgers, A., \& Timmermans, H. (1995). A day in the city: Using conjoint choice experiments to model urban tourists' choice of activity packages. Tourism Management, 16(5), 347-353. https://doi.org/10.1016/0261-5177(95)00035-M

Elliot, S., \& Joppe, M. (2010). Packaging travel on the web: A case study of Ottawa Tourism. 2010 Ttra International Conference.

Greene, W. H. (2000). Econometric Analysis (4th ed.). New York: Prentice Hall.

Guiltinan, J. P. (1987). The Price Bundling of Services: A Normative Framework. Journal of Marketing, 51(April), 74 85. https://doi.org/10.2307/1251130

James, A., Ravichandran, S., Chuang, N. K., \& Bolden, E. (2017). Using Lifestyle Analysis to Develop Lodging Packages for Staycation Travelers: An Exploratory Study. Journal of Quality Assurance in Hospitality and Tourism, 18(4), 387-415. https://doi.org/10.1080/1528008X.2016.1250240

Kahneman, D., \& Tversky, A. (1979). Prospect Theory: An Analysis of Decision under Risk. Econometrica, 47(2), 263292. https://doi.org/10.2307/1914185

Kim, J., Bojanic, D. C., \& Warnick, R. B. (2009). Price bundling and travel product pricing practices used by online channels of distribution. Journal of Travel Research, 47(4), 403-412. https://doi.org/10.1177/0047287508328658

Kim, J. E. J., Kim, P. B., \& Kim, J. E. J. (2018). Different or Similar Choices: The Effect of Decision Framing on Variety Seeking in Travel Bundle Packages. Journal of Travel Research, 57(1), 99-115. https://doi.org/10.1177/0047287516684977

Kim, K., \& Uysal, M. (2003). Perceived Socio-Economic Impacts of Festivals and Events Among Organizers. Journal of Hospitality \& Leisure Marketing, 10(3-4), 159-171. https://doi.org/10.1300/J150v10n03_10

Lim, C. C., \& Bendle, L. J. (2011). Arts tourism in Seoul: tourist-orientated performing arts as a sustainable niche market. Journal of Sustainable Tourism, (March 2012), 1-16.

Louviere, J. J., \& Woodworth, G. (1983). Design and Analysis of Simulated Consumer Choice or Allocation Experiments: An Approach Based on Aggregated Data. Journal of Marketing Research, 20(November), 350-367. https://doi.org/10.2307/3151440

Mayen, C., Marshall, M., \& Lusk, J. (2007). Fresh-cut melon: The money is in the juice. Journal of Agricultural and Applied Economics, 392(3), 597-609. https://doi.org/10.1017/S1074070800023294

McCullough, D. (2002). A user's guide to conjoint analysis. Marketing Research, 14(2), 18.

Naylor, G., \& Frank, K. E. (2001). The effect of price bundling on consumer perceptions of value. Journal of Services 
Marketing, 15, 270-281. https://doi.org/10.1108/EUM0000000005506

Noone, B. M., \& Mattila, A. S. (2009). Hotel revenue management and the Internet: The effect of price presentation strategies on customers' willingness to book. International Journal of Hospitality Management, 28(2), 272-279. https://doi.org/10.1016/j.ijhm.2008.09.004

O'Connor, N., \& Flanagan, S. (2008). The integration of film-induced tourism and destination branding in Yorkshire, UK. International Journal of Tourism Research, 423-437. https://doi.org/10.1002/jtr.676

Phillips, L., \& Schofield, P. (2007). Pottery, Pride, and Prejudice: Assessing Resident Images for City Branding. Tourism Analysis, 12(5), 397-407. https://doi.org/10.3727/108354207783228019

Rose, N. L. (2004). Selling complex leisure travel online--focus on dynamic packaging technology. Report. Phocuswright.

Tanford, S., Baloglu, S., \& Erdem, M. (2012). Travel Packaging on the Internet: The Impact of Pricing Information and Perceived Value on Consumer Choice. Journal of Travel Research, 51, 68-80. https://doi.org/10.1177/0047287510394194

Usakli, A., \& Baloglu, S. (2011). Brand personality of tourist destinations: An application of self-congruity theory. Tourism Management, 32(1), 114-127. https://doi.org/10.1016/j.tourman.2010.06.006

Ward, S., \& O'Regan, T. (2009). The Film Producer as the Long-stay Business Tourist: Rethinking Film and Tourism from a Gold Coast Perspective. Tourism Geographies, 11(2), 214-232. https://doi.org/10.1080/14616680902827175

Zhao, M., \& Chen, Y. (2017). A Study on Behavioral Preferences for Air Travel Packages: The Sea Island Destination of Bali as an Example. Boletin Técnico, 55(11).

\section{Copyrights}

Copyright for this article is retained by the author(s), with first publication rights granted to the journal.

This is an open-access article distributed under the terms and conditions of the Creative Commons Attribution license which permits unrestricted use, distribution, and reproduction in any medium, provided the original work is properly cited. 